\title{
Faktor-Faktor Penyebab Terjadinya Perkosaan Incest
}

\author{
Desilasidea Cahya Zalzabella \\ Fakultas Hukum, Universitas Muhammadiyah Yogyakarta \\ Email : desilasidea.cahya.2014@law.ac.id
}

\author{
Info Artikel \\ Kata Kunci : \\ Aborsi, \\ Perkosaan Incest, \\ Pertanggungjawaban Pidana \\ Perjalanan Artikel : \\ Diterima : 10 Januari 2020 \\ Direview : 01 Februari 2020 \\ Direvisi : 20 Maret 2020 \\ Dipublikasikan : Maret 2020
}

DOI: 10.18196/ijclc.v1i1.9156

\section{Pendahuluan}

Menjalani kehamilan sangat diharapkan dan di idam - idamkan oleh kebanyakan wanita di seluruh dunia, namun ada juga wanita yang menjalani kehamilannya dengan terpaksa dan menjadi cobaan dalam hidupnya bukan dijadikan sebagai anugerah karena kehamilan tersebut tidak dikehendaki yang disebabkan oleh perkosaan. Terlepas dengan alasan yang menyebabkan kehamilan tersebut, aborsi dilakukan karena adanya kehamilan yang tidak dikehendaki tersebut. Hal ini karena aborsi yang terjadi sudah menjadi aktual, banyak terjadi dimana - mana, dikalangan siapa saja, seperti remaja, bahkan orang dewasa sekalipun. Aborsi terjadi dimana seseorang terdesak dan tidak mau bertanggung jawab atas apa yang dilakukan. Pergaulan bebas menjadi faktor utama terjadinya kehamilan yang tidak dikehendaki dan tidak ingin bayi yang dikandungnya lahir ke dunia. Padahal, kehamilan adalah anugerah yang telah diberikan, justru telah menjadi beban oleh seseorang yang tidak bertanggung jawab. Ironis sekali memang, karena terlepas dari masalah ini, masih banyak wanita bahkan suami istri diluar sana yang menginginkan kehadiran buah hati, karena belum diberikan keturunan. Terbongkarnya kasus abortus provokatus di Jakarta diawali dengan ditemukannya sebelas jasad orok dibawah jembatan Warakas pada bulan November tahun 1997 dan sempat menjadi bahan berita skala Nasional. Tindak pidana pemerkosaan semakin dikecam apabila orang yang melakukan pemerkosaan tersebut masih mempunyai hubungan kekerabatan atau 
hubungan darah dengan korban pemerkosaan tersebut (incest). Seperti ayah dengan anaknya, paman dengan keponakannya, kakak dengan adiknya, bahkan seorang anak terhadap ibunya. Dr. Ramonasari, Kepala Devisi Kesehatan Reproduksi Perkumpulan Keluarga Berencana Indonesia (PKBI) Jakarta. Perempuan kelahiran 19 Mei 1956 yang juga pernah bekerja sebagai koordinator Klinik Griya Sahari PKBI dan aktif sebagai trainer sex education HIV/ AIDS, mengomentari seputar incest dari perspektif medis mengemukakan, " incest adalah hubungan badan atau hubungan seksual yang terjadi antara dua orang yang mempunyai ikatan pertalian darah, dalam hal ini hubungan seksual sendiri ada yang bersifat sukarela, dan ada yang bersifat paksaan, yang paksaan itulah yang dinamakan perkosaan". Jika hal itu terjadi antara dua orang yang bertalian darah itulah yang dinamakan incest, dan kasus incest yang kebanyakan diketahui dan terungkap di masyarakat umumnya karena terjadi perkosaan, penipuan, penganiayaan. Seperti ayah kandung yang menggauli putrinya atau paman yang memperkosa keponakannya, dan lain-lain. ${ }^{1}$

Kekerasan seksual terhadap anak (perempuan) khususnya perkosaan incest hingga saat ini terus terjadi, baik yang dilaporkan oleh korban atau tidak oleh korban, keluarga atau masyarakat. Penelitian Pusat Kajian Anank dan Perlindungan Anak (PKPA) terhadap empat media cetak terbitan Medan tahun 1999 menemukan 95 kasus perkosaan, 17 kasus pelecehan seksual dan 16 kasus penipuan atau ingkar janji terhadap anak perempuan. Tahun 2000 terjadi 81 kasus pelecehan seksual 16 kasus penipuan atau ingkar janji dan 8 kasus sodomi. Dari 81 kasus ini, 23 kasus adalah incest yang terjadi pada anak usia 1 sampai dibawah 18 tahun. Tahun 2001 terjadi 84 kasus perkosaan, 8 kasus pelecehan seksual, 4 ingkar janji, 3 kehamilan tak diinginkan dan 4 kasus sodomi. Dari 84 kasus tersebut, 27 adalah incest. $^{2}$

Korban perkosaan membutuhkan banyak dukungan, perlindungan dan bantuan. Menjadi korban perkosaan saja sudah berat apalagi ditambah dengan terjadinya kehamilan akibat perkosaan tersebut. Korban akan terus dibayang-bayangi oleh peristiwa perkosaan tersebut yang menyebabkan terjadinya kehamilan yang terus akan menghantuinya dan wanita korban perkosaan tersebut masih harus dihadapkan pada persoalan bagaimana status hukum anak yang dikandungnya apalagi jika yang melakukan perkosaan tersebut masih merupakan saudara sedarah (incest).

Aborsi dengan alasan perkosaan, terutama perkosaan incest, masih menjadi perdebatan oleh banyak kalangan. Kitab Undang-Undang Hukum Pidana (KUHP) sebagai dasar hukum pidana di Indonesia sama sekali melarang tindakan aborsi, tetapi Undang-Undang Nomor 36 Tahun 2009 tentang Kesehatan dan Peraturan Pemerintah No. 61 Tahun 2014 masih memberi ruang terjadinya aborsi dengan alasan tertentu, yaitu dengan alasan adanya indikasi medis. Indikasi medis di dalam undang-undang hanya menyebutkan secara limitatif, apakah perkosaan incest dapat dijadikan indikasi medis untuk melakukan aborsi sehinggga meniadakan pidana dari perbuatan aborsi tersebut.

Berdasarkan dari latar belakang masalah sebagaimana diuraikan di atas, maka peneliti mengambil judul "FAKTOR-FAKTOR PENYEBAB PERKOSAAN INCEST".

\section{Rumusan Masalah}

Berdasarkan masalah di atas, maka perumusan masalah dalam penulisan ini sebaagai berikut: Apa saja faktor-faktor penyebab perkosaan incest?

1 Suryono Ekotomo, Abortus Provokatus Bagi Korban Perkosaan Perspektif Viktimologi, Kriminologi dan Hukum Pidana, Universitas Atma Jaya, Yogyakarta, 2001, hlm.19.

2 Dwi Hapsari Retnaningrum, Incest Sebagai Bentuk Manifestasi Kekerasan Terhadap Perempuan. Jurnal Hukum Pandecta, Fakultas Ilmu Hukum, Universitas Negeri Semarang. Semarang, 2009, Vol. 9 No. 1. 


\section{Metode Penelitian}

\section{Jenis Penelitian}

Jenis penelitian yang penulis gunakan yaitu jenis penelitian hukum normatif, penelitian hukum yang menggunakan sumber data sekunder atau data yang diperoleh melalui bahan-bahan pustaka.

\section{Teknik Pengumpulan Data}

Penelitian ini penulis mendapatkan data melalui bahan-bahan kepustakaan berupa peraturan perundang-undangan, buku-buku, dokumen-dokumen resmi, pendapat para ahli, catatan kuliah, surat kabar dan penelitian yang telah ada sebelumnya yang berkaitan dengan judul penelitian.

\section{Teknik Pengolahan Data}

Setelah data terkumpul penulis dalam hal ini melakukan pengolahan data dengan melakukan klasifikasi terhadap data dan bahan hukum yang telah terkumpul secara sistematis.

\section{Analisis Data}

Data penelitian ini dianalisa dengan menggunakan analisis deskriptif, yaitu berusaha menganalisa data dengan menguraikan dan memaparkan secara jelas dan apa adanya mengenai obyek yang diteliti. Data-data dan informasi yang diperoleh dari obyek penelitian dikaji dan dianalisa dikaitkan dengan teori dan peraturan yang berlaku yang bertujuan untuk memecahkan permasalahan yang diangkat.

\section{Hasil Penulisan dan Analisis}

Kasus perkosaan merupakan kasus yang sangat meninggalkan trauma pada korbannya, terlebih jika pelaku dari kejahatan tersebut merupakan seseorang yang memiliki hubungan darah dengan korban, trauma bisa jadi bukan hanya dialami oleh korban akan tetapi bisa juga dialami oleh keluarga dan yang memiliki hubungan darah dengan si pelaku. Tindak pidana perkosaan dengan korban yang memiliki hubungan darah dengan pelaku ini disebut dengan perkosaan Incest, yang mana bisa dilakukan oleh ayah kepada anak perempuannya, kakak dengan adiknya atau sebaliknya, paman dengan keponakan, bahkan anaknya kepada ibunya.

Korban perkosaan pada umumnya mengalami tekanan psikis yang kuat sehingga jelas terlihat adanya daya paksa atau overmarcht. Overmarcht merupakan daya, dorongan, paksaan yang membuat seseorang tidak berdaya menghadapinya yang ada pada saat tindak pidana dilakukan maupun jauh sebelumnya, namun memuncak dan memunculkan situasi stress yang tak terarahkan. Korban perkosaan banyak yang mengalami depresi berat, kelesuan kronis, gangguan tidur, mimpi buruk, merasa terisolasi dari masyarakat sekitar, dan menarik diri karna malu dengan apa yang dialaminya. Korban yang mengalami tekanan emosional dan fisik yang hebat, dapat melakukan tindakan diluar kendali karena penderitaan psikis yang dialaminya setelah diketahui bahwa korban perkosaan mengalami kehamilan.

Mengenai kasus perkosaan Incest khususnya yang ditangani Pengadilan Negeri Sleman yang terjadi selama tahun 2014 sampai dengan tahun 2018 dapat ditunjukkan sebagai berikut :

Tabel 1

Kasus Perkosaan Incest yang ditangani Pengadilan Negeri Sleman selama tahun 2015-2018

\begin{tabular}{|c|c|l|c|c|c|}
\hline No & Tahun & \multicolumn{1}{|c|}{ Nomor Putusan } & Terdakwa & Korban & Jumlah \\
\hline 1 & 2014 & 214/Pid.Sus/2014/PN.Sleman & Kentos & FA (13thn) & 1 \\
\hline 2 & 2015 & $430 /$ Pid.Sus/2015/PN.Sleman & Gundul & OE (16thn) & 1 \\
\hline 3 & 2016 & 506/Pid.Sus/2016/PN.Sleman & HK & NR (3thn) & 1 \\
\hline 4 & 2017 & - & - & - & - \\
\hline 5 & 2018 & 276/Pid.Sus/2018/PN.Sleman & B & KAP (15thn) & 1 \\
\hline
\end{tabular}

Sumber: Data diolah 
Berdasarkan tabel di atas, jenis perkosaan Incest sebagai salah satu tindak pidana yang mempunyai kuantitas sedikit. Dari tahun 2014 sampai dengan tahu 2018 terdapat 4 kasus perkosaan Incest. Korban dalam kasus perkosaan Incest sebagaimana yang diadili di Pengadilan Negeri Sleman adalah berjenis kelamin perempuan. Kejahatan tersebut tidak hanya dialami oleh perempuan usia remaja akan tetapi juga dialami oleh anak balita. Hal tersebut menandakan bahwa kejahatan seksual tindak memandang usia korban maupun status hubungan antara pelaku dan korban.

Korban perkosaan Incest lebih memiliki tekanan psikis dan bahkan lebih memiliki niat untuk menggugurkan janinnya apabila jika mengalami kehamilan. Korban mengalami kehamilan yang tidak diinginkan akibat perilaku jahat orang terdekatnya. Orang yang seharusnya melindungi dan menyayangi korban justru menjadi orang yang mengerikan untuk korban.

Undang-Undang 26 Tahun 2000 tentang Hak Asasi Manusia mengatur perihal hak perempuan salah satunya tentang jaminan hak reproduksi perempuan seperti yang dijelaskan pada Pasal 49 ayat 3 yang berbunyi, hak khusus yang melekat pada diri perempuan dikarenakan fungsi reproduksinya, dijamin dan dilindungi oleh hukum. Hak-hak reproduksi adalah merupakan hak asasi manusia dan dijamin oleh Undang-Undang. Berdasarkan pasal 72 Undang-Undang Kesehatan, kehamilan yang tidak dikehendaki akibat perkosaan, jelas itu melanggar hak-hak reproduksi korban perkosaan. Demi memberikan jaminan dan perlindungan hukum terhadap hak-hak reproduksi korban perkosaan sebagai bentuk hak asasi manusia, maka terdapat legalisasi aborsi bagi perempuan yang hamil akibat perkosaan.

Faktor kondisi sosial yang sering memungkinkan pelanggaran incest adalah rumah yang sempit dengan penghuni yang berdesakan, alkoholisme, isolasi geografis, sehingga sulit mencari hubungan dengan anggota keluarga yang lain. ${ }^{3}$

Penyebab Incest lainnya yaitu antara lain ruangan rumah yang baik memungkinkan orang tua, anak, dan saudara pisah kamar. Sedangkan hubungan incest antara ayah dengan anak perempuannya dapat terjadi sehubungan dengan keberadaan penyakit mental serius pada pihak ayah. Jenis-jenis incest berdasarkan penyebabnya adalah :

a. Incest yang terjadi secara tidak sengaja, misalnya kakak-adik lelaki perempuan remaja yang tidur sekamar, bias tergoda melakukan eksperimentasi seksual sampai terjadi incest.

b. Incest akibat psikopatologi berat. Jenis ini biasa terjadi antara ayah yang alkoholik atau psikopatik dengan anak perempuannya. Penyebabnya adalah kondornya kontrol diri akibat alkohol atau psikopati sang ayah.

c. Incest akibat pedofilia, misalnya seorang lelaki yang haus menggauli anak-anak perempuan dibawah umur, termasuk anaknya sendiri.

d. Incest akibat contoh buruk dari ayah. Seorang lelaki menjadi senang melakukan incest karena meniru ayahnya melakukan perbuatan yang sama dengan kakak atau adik perempuannya.

e. Incest akibat patologi keluarga dan hubungan perkawinan yang tidak harmonis. Seorang suamiayah yang tertekan akibat sikap memusuhi serba mendominasi dari istrinya bisa terpojok melakukan incest dengan anak perempuannya. ${ }^{4}$

Ada beberapa penyebab atau pemicu timbulnya incest. Akar dan penyebab tersebut tidak lain adalah karena pengaruh aspek struktural, yakni situasi-situasi menyebabkan ketidakberdayaan pada diri individu. Khususnya apabila ia seorang laki-laki (notabene cenderung dianggap dan menganggap diri sendiri lebih berkuasa) akan sangat terguncang, dan menimbulkan ketidakseimbangan mental-psikologis. Dalam ketidak berdayaannya tersebut, tanpa adanya iman sebagai kekuatan internal/spiritual, seseorang akan dikuasai oleh dorongan primitive, yakni dorongan seksual ataupun agresifitas. Faktor-faktor struktural tersebut antara lain adalah :

a. Konflik Budaya dengan adanya kemajuan teknologi. Perubahan social terjadi begitu cepatnya seiring dengan perkembangan teknologi. Alat-alat komunikasi seperti radio, televise, HCD, HP,

3 Sawitri Supardi Sadarjoen, Bunga Rampai Kasus Gangguan Psikoseksual, Bandung, Refika Aditama, 2005, hlm. 7475.

4 Kartini, Kartono., Psikologi Abnormal dan Abnormalitas Seksual, Jakarta, Mandar Maju,1989,hlm. 225. 
koran, dan majalah telah masuk ke seluruh pelosok wilayah Indonesia. Seiring dengan itu, masuk pula budaya-budaya baru yang sebetulnya tidak cocok dengan budaya dan normanorma setempat. Orang dengan mudah mendapat berita criminal seks melalui tayangan televise maupun tulisan di koran dan majalah. Juga informasi dan pengalaman pornografi dan berbagai jenis media. Akibatnya, tayangan televise, VCD, dan berita di koran atau majalah yang sering menampilkan kegiatan seksual incest serta tindak kekerasannya, dapat menjadi model bagi mereka yang tidak bias mengontrol nafsu birahinya. ${ }^{5}$

Faktor-faktor lain yang melatarbelakangi terjadinya incest, yaitu :

1) Faktor rendahnya pendidikan dan ekonomi;

Rendahnya tingkat pendidikan formal dalam diri seseorang dapat menimbulkan dampak terhadap masyarakat dan yang bersangkutan mudah terpengaruh melakukan suatu kejahatan tanpa memikirkan akibat dari perbuatannya. Salah satu delik yang berhubungan karena pelakunya memiliki pendidikan formal yang rendah adalah tindak pidana kesusilaan terutama incest. Karena memiliki tingkat pendidikan yang rendah para pelaku tidak berpikir bahwa dengan melakukan perbuatan tersebut dapat merusak keluarga dari pelaku tersebut dan watak anak yang menjadi korban. Karena pendidikan yang rendah maka berhubungan dengan taraf ekonomi, dimana ekonomi juga merupakan salah satu penyebab seseorang melakukan suatu perbuatan yang melanggar norma hukum.

Menurut Aristoteles, kemiskinan menimbulkan kejahatan dari pemberontakkan, kejahatan yang besar tidak diperbuat untuk memperoleh apa yang perlu untuk hidup, tetapi untuk kemewahan. ${ }^{6}$

Menurut Thomas Aquino, pengaruh kemiskinan atas kejahatan yaitu orang kaya yang hidup untuk kesenangan dan memboros-boroskan kekayaannya, jika suatu kali jatuh miskin, makan mudah menjadi pencuri. ${ }^{7}$

Dari pendapat para ahli di atas, dilihat bahwa faktor ekonomi juga ikut berpengaruh terjadinya kejahatan termasuk tindak pidana incest.

2) Faktor Lingkungan atau Tempat Tinggal

Kejahatan asusila merupakan tindak manusia terhadap manusia lainnya didalam masyarakat. Oleh karena itu manusia adalah anggota dari masyarakat, maka kejahatan asusila tidak dapat dipisahkan dari masyarakat setempat. Lingkungan sosial tempat hidup seseorang banyak berpengaruh dalam membentuk tingkah laku kriminal, sebab pengaruh sosialisasi seseorang tidak akan lepas dari pengaruh lingkungan. Bahwa bukan hanya pengaruh faktor lingkungan sosial yang ikut berperan akan timbulnya kejehatan tetapi faktor tempat tinggal pun ikut juga mempengaruhi kejahatan seperti tindak pidana asusila terutama tindak pidana incest, dimana rumah hanya memiiki satu kamar sehingga untuk tidur biasanya akan bersama orang tua dengan anaknya.

3) Faktor Alkohol

Kasus incest juga terjadi karena adanya stimulasi diantaranya karena dampak alkohol. Orang yang dibawah pengaruh alkohol sangat berbahaya karena ia menyebabkan hilangnya dengan sekonyong-konyong daya menahan diri dari si peminum. Diluar beberapa hal yang terjadi, dimana si peminum justru untuk menimbulkan kehilangan daya menahan diri, bahwa alkohol jika dipergunakan akan membahayakan manusia pertama jiwanya paling lemah. Begitu seseorang yang mempunyai gangguan-gangguan dalam seksualitasnya, dimana minuman alkohol melampui batas yang menyebabkan dirinya tak

5 http:/nauny290590.wordpress.com/2010/03/31/incest-pernikahan-sedarah/, diakses pada hari Senin, 10 Januari 2019, pukul 20.00 WIB.

6 Aristoteles dalam Buku Topo Santoso dan Eva Zulfa Achjani., Kriminologi, Jakarta, Raja Grafindo Persada, 2001, hlm. 11.

7 Thomas Aquino dalam ibid 
dapat menahan nafsunya lagi, dan akan mencari kepuasan seksualnya, bahkan dengan memperkosa anaknya sendiri atau keluarganya.

4) Faktor Kurangnya Pemahaman Terhadap Agama

Penyebab terjadinya suatu kejahatan ditentukan pada persoalan keharmonisan, agama atau hubungan antara manusia dengan tuhan. Menurut teori ini semakin jauh hubungan seseorang dengan tuhannya melalui perantara agama yang dianutnya maka semakin dekat pula maksud seseorang untuk melakukan kejahatan. Jika seseorang tidak memahami betul agamanya, akan menyebabkan imannya menjadi lemah. Kalau sudah demikian keadaannya, maka seseorang mudah sekali untuk melakukan suatu hal yang buruk.

5) Peranan Korban

Peranan korban atau sikap korban sangat menentukan seseorang untuk melakukan kejahatan terhadapnya, termasuk kejahatan asusila. Sebagaimana yang dikemukakan oleh Von Henting bahwa "Ternyata korbanlah yang kerap kali merangsang seseorang untuk melakukan kejahatan dan membuat orang menjadi penjahat." 8

Semakin maraknya kasus incest menunjukkan bahwa posisi seorang anak sangat rawan menjadi korban kekerasan seksual, terlebih lagi pelakunya adalah orang yang seharusnya menjadi pelindungnya. Rumah tidak dapat dikatakan sebagai tempat teraman lagi, banyak kasus-kasus yang terjadi didalam sebuah keluarga. Pelaku melakukan aksinya mulus-mulus saja, bagaikan tidak ada rintangan, karena di dalam sebuah keluarga sulit dipercaya adanya perkosaan, serta pelakunya kakak terhadap adik dan orang tuanya pula. Sungguh tidak disangka di dalam rumah terjadi perkosaan.

Dilihat kasus yang menimpa WA, seorang anak berusia 15 tahun di Jambi, korban perkosaan yang dilakukan oleh kakak kandungnya sendiri sampai hamil ada faktor eksternal yaitu pengaruh teknologi sebagai perubahan sosial. Perubahan sosial terjadi begitu cepat seiring perkembangan teknologi. Alat-alat komunikasi seperti radio, televisi, HCD, HP, koran dan majalah telah masuk ke seluruh pelosok Indonesia. Seiring dengan itu, masuk pula budaya-budaya baru yang sebetulnya tidak cocok dengan budaya dan norma yang ada di Indonesia. Orang-orang dengan mudah mendapatkan berita kriminal seks melalui tayangan televisi maupun koran dan majalah. Juga informasi dan pengalaman pornografi dari berbagai jenis media. Akibatnya, tayangan televisi, VCD, dan berita koran atau majalah yang sering menampilkan kegiatan seksual incest serta tindak kekerasannya, dapat menjadi model bagi mereka yang tidak bisa mengontrol nafsu birahinya. Banyaknya video porno yang mudah didapat dan diakses di internet pun membuat anak dengan mudahnya melihat video dewasa itu secara bebas. Kurang adanya pengawasan juga terhadap anak dari orang tua sehingga kadang orang tua tidak memperhatikan dan memantau anaknya dalam bermain HP atau film yang mereka tonton. Kurang dekatnya anak dengan orang tua juga membuat mereka kurang terbuka karena minimnya komunikasi orang tua terhadap anak.

Faktor pendidikan juga mempengaruhi anak melakukan perkosaan incest contohnya kurangnya edukasi seks yang didapat anak dan kurangnya yang diberikan orang tua juga menyebabkan banyak terjadinya kejahatan seksual pada anak.

Faktor lingkungan juga dapat mempengaruhi anak berbuat kejahatan seksusal. Karena orang tua kurang mengawasi pergaulan anak. Sehingga bisa saja dia terpengaruh oleh temannya yang melihat video porno sehingga dia penasaran dan juga ikut melihat video tersebut sehingga membuat anak melakukan kejahatan seksual. Contohnya perilaku AS yang memperkosa WA, adik kandungnya sendiri setelah menonton video porno.

8 Von Henting dalam Buku Ninik Widiyanti dan Yulius Waskita., Kejahatan Dalam Masyarakat dan Pencegahannya, Jakarta, Bina Aksara, 1987, hlm. 133. 
Sama halnya yang terjadi pada kasus perkosaan anak dengan putusan Nomor 430/PID.SUS/2015/PN.Smn yang dilakukan oleh :

$\begin{array}{ll}\text { Nama } & \text { : Gundul } \\ \text { Tempat Lahir } & \text { : Yogyakarta } \\ \text { Umur/Tgl Lahir } & \text { : 42 Tahun/ 12 Maret } 1972 \\ \text { Jenis Kelamin } & \text { : Laki-Laki } \\ \text { Kewarganegaraan } & \text { : Indonesia } \\ \text { Tempat Tinggal } & \text { : Yogyakarta } \\ \text { Agama } & \text { : Islam } \\ \text { Pekerjaan } & \text { : Buruh } \\ \text { Kronologi } & :\end{array}$

Bahwa terdakwa Gundul pada bulan Desember tahun 2014 sekira jam 22.00 WIB. Atau setidaktidaknya pada waktu lain dalam tahun 2014 bertempat tinggal di Yogyakarta alamat disamarkan, yang dengan sengaja melakukan tipu muslihat, serangkaian kebohongan, atau membujuk anak yaitu saksi Oka yang berumur 16 Tahun yang lahir pada tanggal 22 Oktober 1998 sesuai surat kelahirannya. Bermula saat Oka sedang tidur dengan kedua adiknya didalam kamar dalam keadaan terkunci kemudian terdakwa menjugil pintu kamar, membangunkan saksi Oka dan mengatakan "AYO AKU NJALUK (HUBUNGAN BADAN) PISAN WAE, SESOK ORA MENEH (AYO AKU MINTA HUBUNGAN BADAN, SEKALI SAJA, BESOK TIDAK LAGI)" lalu saksi tidak menjawab kemudian terdakwa melorotin celana dalam saksi dan juga celananya selanjutnya terdakwa menciumi pipi saksi dan menindih saksi sambil memasukkan alat kelaminnya yang sudah tegang kedalam kelamin saksi Oka, lalu terdakwa menggoyang-goyangkan pantatnya naik turun hingga alat kelamin terdakwa mengeluarkan sperma didalam kelamin saksi Oka kemudian terdakwa membersihkan alat kelaminnya lalu memakai celananya sendiri sedangkan saksi Oka memakai celananya sendiri, lalu terdakwa keluar kamar dan menutup pintu kamar lalu saksi kembali tidur. Kedua adik saksi mendengar namun tidak berani bangun karena takut terhadap terdakwa kemudian saat terdakwa pergi, kedua adik saksi Oka menghubungi Sulasih ibu Oka untuk pulang kerumah. Terdakwa sudah melakukan hubungan layaknya suami istri sebanyak 10 (sepuluh) kali terhadap Oka ditempat tidur Oka hingga saksi hamil dalam usia kandungan berumur 6 (enam) bulan.

Perbuatan terdakwa sebagaimana diatur dan diancam pidana dalam pasal 81 Ayat (2) UndangUndang No. 35 Tahun 2014 Tentang Perubahan Atas Undang-Undang No. 23 Tahun 2002 Tentang Perlindungan Anak. Jo Pasal 64 ayat (1) KUHP.

Dengan adanya kasus perkosaan incest tersebut, faktor- faktor penyebab terjadinya incest pada Oka yaitu kurangnya pengawasan dari orang tua kepada anakya terutama Ibu. Ibu lebih harus meperhatikan anak, karna perkosaan sendiri dilakukan oleh ayah kandungnya sendiri. Kurang dekatnya hubungan keharmonisan ayah terhadap anak juga dapat mempengaruhi terjadinya perkosaan incest tersebut sehingga kurang adanya rasa sayang terhadap anak dan hasrat untuk melindugni anaknya yang seharusnya itu dilakukan oleh ayah terhadap anaknya terutama anak perempuannya justru malah terjadi sebaliknya.

Faktor mendasar penyebab perkosaan incest bahkan kasus perkosaan lainnya adalah faktor kurangnya pemahaman terhadap agama. Penyebab terjadinya kejahatan ditentukan pada persoalan keharmonisan, agama atau hubungan antara manusia dengan Tuhannya. Semakin jauh hubungan manusia dengan Tuhannya, semain dekat pula maksud atau niat seseorang untuk melakukan kejahatan. Kurang dan lemahnya iman pada dirinya membuat seseorang dengan mudahnya berbuat hal yang buruk.

Adanya kepastian hukum merupakan harapan bagi pencari keadilan terhadap tindakan sewenang-wenang dari aparat penegak hukum yang terkadang selalu arogansi dalam menjalankan tugasnya sebagai penegak hukum. Keadilan merupakan salah satu tujuan hukum yang paling banyak dibicarakan sepanjang perjalanan sejarah filsafat hukum. Kemanfaatan hukum, adalah sejumlah rumusan pengetahuan yang ditetapkan untuk mengatur lalu lintas perilaku manusia sehingga dapat berjalan lancar, tidak saling tubruk dan berkeadilan. Ketiganya harus ada kompromi, harus mendapat perhatian secara proposional seimbang. Idealnya, hukum memang harus mengakomodasikan ketiganya. 


\section{Simpulan dan Saran}

\section{Simpulan}

Untuk faktor-faktor penyebab perkosaan incest cukup jelas, dan faktor-faktor yang terjadi dari korban perkosaan WA juga terjadi pada korban-korban perkosaan seperti yang saya tulis di tabel menurut data perkosaan incest pada Pengadilan Negeri Sleman. Ada faktor lain yang mempengaruhi seperti faktor lingkungan. Kasus pada tabel diatas bukan kakak adik melainkan anak kepada anak kandungnya, seperti yang dilakukan Gundul sebagai ayah terhadap Oka anak kandungnya sendiriyang masih dibawah umur sampai hamil. Namun berbeda dengan kasus AS yang memperkosa WA adik kandungnya hingga hamil dan WA dengan terpaksa melakukan aborsi, Oka yang diperkosa ayah kandungnya sampai hamil 6 bulan tetap mempertahankan kandungannya. Oka masih dibawah umur dan dia harus menerima nasibnya menjadi Ibu diumur yang masih sangat muda atas perilaku buruk ayah kandungnya sendiri.

Sangat miris itu terjadi karena figur seorang ayah yang seharusnya dijadikan panutan dan tempat berlindung justru menghancurkan masa depan anak, dan itu sudah banyak terjadi di Indonesia. Sebisa mungkin kita harus menghindari atau mencegah faktor-faktor yang menjadi penyebab perkosaan incest tersebut.

\section{Saran}

Perlu adanya pengawasan lebih terhadap anak, menciptakan komunikasi yang baik juga antara orang tua dan anak agar anak selalu terbuka dan dekat dengan orang tua terutama anak dibawah umur, selalu mengajarkan dan menerapkan pelajaran agama agar anak sudah dibekali iman yang baik dan kuat sejak dini, memberikan edukasi terhadap orang tua kepada anaknya bahwa perkosaan incest tidak seharusnya terjadi karena itu merupakan perbuatan yang keji dan berakibat buruk untuk sang anak yaitu anak bisa saja hamil, anak mengalami trauma psikologis yang berat sehingga membuat mental anak terganggu dengan adanya beban berat yang menimpanya. Orang tua harus lebih ketat mengawasi anaknya terutama Ibu karna perkosaan antara ayah kepada anaknya sering terjadi.

Memberikan edukasi bahwa aborsi itu bersifat ilegal. Karena bagaimanapun aborsi yang bersifat ilegal dapat membahayakan jiwa dan keselamatan ibu akibat tidak dilakukan sesuai dengan prosedur dan oleh tenaga kerja yang profesional. Selain itu perkosaan/ hubungan incest dapat merusak keluarga dan dapat dikenakan sanksi pidana. 
Indonesian Journal of Criminal Law and Criminology
Pusat Kajian Hukum Pidana dan Kriminolog

Fakultas Hukum Universitas Muhammadiyah Yogyakarta

Jalan Brawijaya, Kasihan, Bantul, Yogyakarta 55183

Telp. (0274) 387656 Ext. 472

Fax. 0274-387656

E-mail : cclcs@umy.ac.id

\section{DAFTAR PUSTAKA}

\section{Buku}

Kartini, Kartono. 1989. Psikologi Abnormal dan Abnormalitas Seksual, Mandar Maju, Jakarta.

Ninik Widiyarti dan Yulius Waskita. 1987, Kejadian dalam Masyarakat dan Pencegahannya, Bima Askara, Jakarta.

Sawitri Supardi Sadarjoen. 2005. Bunga Rampai Kasus Gangguan Psikoseksual, Refika Aditama, Bandung.

Suryono Ekotama. 2001. Abortus Provokatus Bagi Korban Perkosaan Perspektif Viktimologi, Kriminologi dan Hukum Pidana, Universitas Atma Jaya, Yogyakarta

Topo Surtoso dan Eva Zulfa Achjani. 2001, Kriminologi, Raja Grafindo Persada, Jakarta.

\section{Jurnal}

Dwi Hapsari Retnaningrum, 2009, "Incest Sebagai Bentuk Manifestasi Kekerasan Terhadap Perempuan", Jurnal Hukum Pandecta Fakultas Ilmu Hukum Universitas Negeri Semarang, Vol. 9 No. 1

\section{Internet}

http:/nauny290590.wordpress.com/2010/03/31/incest-pernikahan-sedarah/, diakses pada hari Senin, 10 Januari 2019, pukul 20.00 WIB 